\title{
Effect of Selected Board Characteristics on Financial Voluntary Disclosure among Manufacturing Firms Listed in Nairobi Securities Exchange
}

\author{
Michael Kimeu Kamwana
}

Dr Robert Ombati (PhD)

\author{
School of Business and Economics \\ South Eastern Kenya University \\ Kitui County, Kenya
}

\begin{abstract}
Information asymmetry aids in investment decision making. In several instances listed companies are only required to disclose information as stipulated in international financial reporting and capital market authority guidelines. In some cases, listed companies provide quantitative and qualitative information which may be paramount to decision making amongst different stakeholders. Consequently, the study investigated the effect of selected board characteristics on financial voluntary disclosure among manufacturing firms listed in Nairobi securities in Exchange. Exploratory research was adopted and census of all 10 listed manufacturing applied. Correlation and regression analysis were used to analyse the data. Results of the study revealed positive and significant relationship between board size, independent directorship, audit committee size, gender board diversity board ownership and financial voluntary disclosure. It was concluded that there is need to incorporate independent board membership, match board size with company size, have fully functional audit committee,
\end{abstract}

\section{Introduction}

\section{Background to the Study}

Voluntary disclosure refers to sharing information publicly other than what is required by laws or regulations done for the sake of companies' images, investors and accusation risk avoidance (Tian \& Chen, 2009). It provides both financial and non-financial information. A high degree of disclosure attracts great attention from members of the public and hence increase the investors' confidence which explain the reasoning behind which companies are striving to achieve maximum disclosure. Moreover, it is a way of minimising adverse selection and moral hazards and ultimately reduces information asymmetry (Wang, Sewon \& Claiborne, 2008).

Voluntary disclosure has been classified differently by past studies but this study adopts three categories as done by (Eng \& Mak, 2003; Lim, Matolcsy \& Chow, 2007; Zhou \& Panbunyuen, 2008); strategic information, financial and non-financial information. First, strategic information focuses on the future of the company and the past which conveys the status of the company both national and transnational. Strategic information emerges from company policy, objectives, capital expenditure and research and development expenditure budget.

Second, financial information is expressed in monetary terms that can be evaluated through ratio such as liquidity, profitability, gearing/leverage and investors' ratio, forecasting sales and profit and analysis of market shares. These ratios communicate much about the company financial position and as such they should be computed and summarized for a period mostly three or two years to enhance comparison. Lastly, non-financial information relates to employee and activities that encourage corporate social responsibility such as society, environment (reducing pollution), donations, and charity and so on. For employees' disclosure is concerned about their welfare, any staff training and again (Zhou \& Panbunyuen, 2008).

There are notable key differences on voluntary and compulsory disclosure. First is on time: as Tian and Chen (2009) points outs that compulsory disclosure is fixed for a given period while voluntary disclosure can be done at any right time. Second is on the root of disclosure: compulsory disclosure is monopoly of companies' selfinformation whilst voluntary is for globalization of market and economy. Third difference is on content: compulsory disclosure conveys basic financial information, information on board and top managers, vital related transactions and explanation of important items, whereas voluntary disclosure contains future strategies, research and development plans, forecasts, project analysis, and financial information analysis and so on (Tian \& Chen, 2009). 
Last but not least, voluntary disclosure can be displayed anywhere, for example annual reports, public announcement, booklets, website, road show, etc. whereas compulsory disclosure is normally shown in the annual report, interim report, and season report. Now to sum it all, voluntary disclosure is a significant indicator of the earning quality of a company that would help investors in making better decisions on allocation of their capital.

The age and gender of the board play a great role as board characteristics. Research has shown that boards become less effective as the average age of its members rises. Recent research by African Stock Exchange has shown most of African companies do have one woman on their board of directors even though, a few (one-third) do not have (African Development Bank [ADB], 2015). Presence of audit committee is another feature of board that is imperative as it help to monitor closely the activities by the management. The size and presence of this committee has been found to improve earning quality (Tian \& Chen, 2009).

Gul and Leung (2004) explain CEO duality element exists when CEO serves as the board's chair thereby weakening the monitoring role of the board over the managers. A need to dissociate the role of CEO and that of board chairperson ensures oversight role is carried in the interest of the funders effectively (Hamed, 2014). Empirical studies have revealed that board ownership assists company minimizing the interest to disclose further information while also lowering agency costs (Yanesari, Gerayli, Abadi \& Ma'atoofi, 2012). More importantly in the characteristics is the presence of committee especially audit committee. Previous studies have shown impact of audit committee impacting the firms' disclosure (Hamed, 2014)

\section{Statement of the Problem}

Information asymmetry aids in investment decision making. In several instances listed companies are only required to disclose information as stipulated in international financial reporting and capital market authority guidelines. In some cases, listed companies provide quantitative and qualitative information which may be paramount to decision making amongst different stakeholders. Increased information disclosure has possibilities of boosting investors confidence since there interests will be fully guarded and agency costs will be minimized. Despite of its relevance it has not attracted much empirical enquiry locally with several local extant literature focusing on effect of board characteristics on firm performance or voluntary disclosure on firm performance. Consequently, the current study explored the effect of selected board characteristics on financial disclosure amongst manufacturing companies listed in Nairobi securities exchange.

\section{Objectives of the Study}

The main objective of the study was to examine the effect of selected board characteristics on financial voluntary disclosure of manufacturing companies listed in Nairobi securities exchange. The specific objectives of the study were:

i. To find out the relationship between board size and the financial voluntary disclosure among manufacturing companies listed in NSE.

ii. To establish the relationship between the proportion of independent directors and financial voluntary disclosure among manufacturing companies listed in NSE.

iii. To establish the relationship between size of audit committee and financial voluntary disclosure among manufacturing companies listed in NSE.

iv. To determine the relationship between gender board diversity and financial voluntary disclosure among manufacturing companies listed in NSE.

v. To establish the relationship between board ownership and financial voluntary disclosure among manufacturing companies listed in NSE.

\section{Hypothesis of the Study}

The study tested the following hypotheses:

i. Board size had no significant relationship with financial voluntary disclosure among manufacturing companies listed in NSE.

ii. Independent directorship had no significant relationship on financial voluntary disclosure among manufacturing companies listed in NSE.

iii. Audit committee size had no significant relationship on financial voluntary disclosure among manufacturing companies listed in NSE.

iv. Gender board diversity had no significant relationship on financial voluntary disclosure among manufacturing companies listed in NSE. 
v. Board ownership had no significant relationship on financial voluntary disclosure among manufacturing companies listed in NSE.

\section{Literature Review}

\section{Theoretical Review}

\section{Agency Theory}

This theory was brought forth by Jensen and Meckling (1976) when they posited that an agency relationship applies where individual(s), the principal, enters into a contract with another individual(s), the agent, to carry out some functions that includes decision making. In company setup, managers act as the agents of the company owned by shareholders who are the principal delegating duties or discharging their responsibility to a third party. Due to the different interests of the parties that make up a company, agency costs may arise. In case of abnormal activities shareholders employ monitoring tools at their own cost to inhibit further deterioration while on the other side managers have incurred bonding cost to convince the principals that no harm that would emerge owing to their activities and decisions.

Further cost may be incurred what can be termed as a residual cost that arises when agents diverge from the primary objective of the shareholders, which is to maximize their return (Shehata, 2014). In short, as Jensen and Meckling (1976) posited agency cost would comprise of the cost of monitoring and evaluation, residual cost and bonding cost. There exist agency problems in the principal-agent relationship since management may be more informed owing to access to relevant information while the shareholders on the other hand will depend on the reported information which may not be fully conclusive. And this is referred to as information asymmetry.

With an intention of protecting, management interests may further resolve to earnings management, which in the long run may have a lethal impact on the company value due to concealed true economic firm value (Basiruddin, 2011). Ayemere and Elijah (2015) study of information asymmetry in Nigeria further affirmed that the agency problem can also be controlled by enhancing monitoring tool both internal and external with excessive reporting and auditing the books of account thoroughly and frequently. And as economic theory suggests company's obligation to increase levels of disclosure should lower the information asymmetry element of a company's cost of capital. Conflicts of interest suggested by stakeholder theory, seem to be solved by the agency theory where management realizes that corporate voluntary disclosures is a powerful tool to communicate with stakeholders plus reducing the cost of capital (Hassan \& Melegy, 2015). However, it must be recognized that information might have a negative value, especially if because investors may perceive themselves to be worse off if they consider that the company is disclosing information which might be exploited to their detriment.

The theory is appropriate in the current study since the board members are assigned the responsibility of day to day running of an organization. Since they are agents of the shareholders they ought to continuously disseminate the relevant information to the shareholders for optimal decision making. Information sharing is not free from conflict especially if the shareholders perceive that board members may induce the firm management depending on the level of information access because they have even the confidential information which if misused may lead to insider trading.

\section{Empirical Review}

Ramadhan, (2014) examined the association between board composition, the existence of audit committees, ownership structure and the level of voluntary disclosure in the annual reports of listed companies in Bahrain Stock Exchange. Information was generated using content analysis of annual reports. A disclosure check list consisting of thirty items were identified from previous research and a self-constructed voluntary disclosure index was developed.Descriptive statistics, correlations and regression analysis were used to test the research hypotheses. Contrary to expectations and consistent with some previous empirical studies, the results found that there was no relationship between the extent of voluntarily disclosure and both, board composition and audit committees, but there is a negative and weak relationship with ownership concentrationZhou and Panbunyuen (2008) examined the role of board composition on different levels of voluntary disclosure. The study used secondary data from annual financial statements of companies listed in China and Swenden.

Multiple regression analysis showed that there was a positive and significant relationship between board size and strategic information disclosure, financial information disclosure, non-financial disclosure and the overall disclosure. Although, the study collected panel data among listed companies it used ordinary least squares 
regression analysis and it would have been appropriate to use panel data regression analysis procedure which include pooled effects, fixed effects and random effects regression analysis. Moreover, regression analysis is based on several assumptions and this study did not test the possible violation of any of the five assumptions.

Sweiti and Attayah (2016) investigated the effect of critical factors on voluntary disclosure in Palestine securities exchange. The study hypothesed that voluntary disclosure is influenced by non-executive directors, audit committee, board size, number of shareholders and board activities. The study adopted descriptive research design. Purposive sampling was applied to select 35 listed companies for period 2007 to 2012. Data was analyzed using descriptive statistics, correlation and regression analysis. Regression analysis revealed positive and significant relationship between non-executive directors, audit committee, board size, number of shareholders, board activities and voluntary disclosure in Palestine. It was appropriate to have executed regression analysis assumptions prior to fitting regression models.

Bansal, Lopez-Penez and Lazaro (2018) investigated the effect of board independence on corporate social responsibility disclosure. Moreover, the moderating role of family ownership was examined. Panel research design was adopted and a sample of 29 companies was drawn from 29 countries for a period 2006 to 2014. Data was analyzed using Tobit regression analysis. Results of the study revealed inverse and significant influence of board independence on corporate social responsibility disclosure. Moreover, family ownership had significant moderating effect was reported. It was concluded that family ownership reduces the level of information asymmetry between independent director and management courtesy of family ownership.

Okoth and Coskun (2016) investigated the effect of corporate governance on firm performance. The study adopted descriptive research design and simple random sampling to select non-financial listed companies in Istanbul securities exchange. Secondary data was collected for period 2009 to 2013. Data was analyzed through regression, correlation and descriptive statistics. Results of the study revealed positive and significant effect of board governance index and economic value added. Moreover, there was positive and non-significant effect of governance index and return on assets. It would have been appropriate to adopt data for a long period of time to minimize possibilities of small sample size problem.

Setiany, Hartoko, Suhardjanto and Honggowati (2015) investigated the impact of audit characteristics on financial voluntary disclosure. The study hypothesed that financial voluntary disclosure was dependent on size of audit committee, education heterogeneity of audit committee members, independence of audit committees' members, tenure of audit committee members and frequency of meetings. Purposive sampling was used to select 100 Indonesian listed companies which comprises of its index. Results of the study revealed that financial voluntary disclosure was dependent on audit committee size, audit committee tenure and independence of audit committee meetings. To minimize model over specification there is need to incorporate alternative corporate governance attributes. This will ultimately investigate the strength of each attribute on financial voluntary disclosure.

Fakhari and Pitenoei (2017) investigated the impact of audit committee and its characteristics on firm information environment. Audit characteristics were operationalized as independence, financial knowledge, gender diversity and audit committee size. Panel research design was adopted and panel data collected from 2008 to 2015. Purposive sampling was used to select 41 companies. Data was analyzed through descriptive, correlation and regression analysis. Results of the study revealed positive and significant effect of audit committee independence, expertise and firm information environment. In addition, there was no significant influence between audit committee gender composition and information environment.

Gul, Srinidhi and $\mathrm{Ng}$ (2011) supported that there is positive relationship between women on the board and the three variables, abnormal return in complex environment; strategic control and stock price in formativeness respectively. This relationship can only be explained by stakeholder theory and not the agency theory unlike earlier suggested. As agency theory explains, promoting a greater number of females tends to improve or impair corporate governance which would further be translated to the financial performance. Latif, Shahid, Haq, Waqas and Arshad (2018) investigated the impact of corporate governance on firm performance of Manufacturing companies in Kenya. Panel research design was adopted and secondary data collected from 12 manufacturing companies from 2005 to 2012. Data was analysed using regression, correlation and descriptive statistics. Results of the study revealed positive and significant impact of corporate governance on firm performance of manufacturing companies in Pakistan. It would have been appropriate to report panel data diagnostics tests in addition to regression modelling. 
From the foregoing literature the following conceptual framework was drawn:

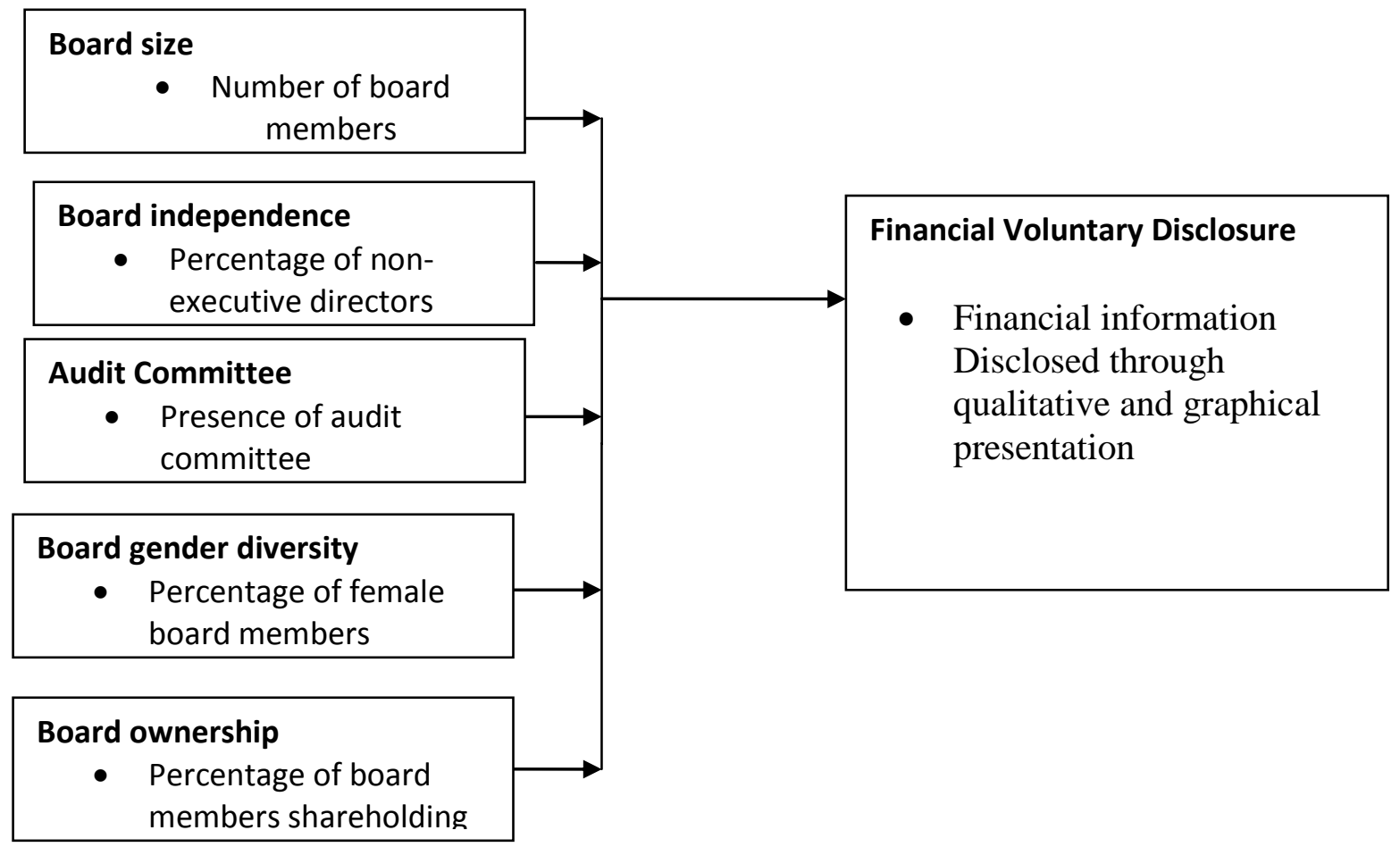

\section{Research Methodology}

The current study will be based on exploratory research design. The design was appropriate since the study sought to examine the effect of selected board characteristics on financial voluntary disclosure of listed manufacturing companies in Kenya. Secondly, a census of 10 listed manufacturing companies was carried out. These companies were: BOC Kenya, British American Tobacco Kenya ltd, Carbacid investments 1td, East Africa Breweries ltd, Mumias Sugar Company ltd, Unga Group ltd, Eveready East Africa ltd, Kenya Orchards ltd, A. Baumann Co ltd and Flame Tree Group Holding Ltd. Secondary data was collected from annual financial statements using data collection sheets. Fixed effects model assumes that heterogeneous groups or time had different intercepts, while random affects models assumes there are differences in disturbance or the error term. Since there was a dilemma in choosing between random and fixed effects, Hausman test was used to decide on the best model to apply between random effects and fixed effects model. According to Hausman (1978) there will be enough to warrant rejection of the null hypothesis which hypothesis that the model has random effects against the alternative which states that the model had fixed effects. A multiple regression model for panel analysis can be given as follows:

$Y_{i, t}=C+\beta_{1} X_{1 i, t}+\beta_{2} X_{2 i, t}+\beta_{3} X_{3 i, t}+\beta_{4} X_{4 i, t}+\beta_{5} X_{5 i, t}+\dot{\varepsilon}_{i, t}$

$\mathrm{Y}=$ Voluntary Disclosure, $\mathrm{X} 1=$ Board Size, $\mathrm{X}_{2}=$ Independent Directors, $\mathrm{X}_{3}=$ Audit Committee, $\mathrm{X}_{4}=$ Gender diversity, $\mathrm{X} 5=$ Board ownership, $\dot{\boldsymbol{\varepsilon}}_{\mathrm{i}, \mathrm{t}}=$ error term, $\mathrm{i}=$ the specific firm, $\mathrm{t}=$ time in years

\section{Results and Discussion}

\section{Correlation Analysis}

Karl Pearson correlation was used to show the strength of the effect of selected board characteristics on financial voluntary disclosure of listed manufacturing companies in NSE. As shown in Table 1, there was positive and significant relationship between financial voluntary disclosure and board size of listed manufacturing companies (rho $=0.257, \mathrm{p}$ value $<0.05$ ). Secondly, there was positive and significant relationship between independent directors and financial voluntary disclosure of listed manufacturing companies in NSE (rho $=0.351, \mathrm{p}$ value $<0.05)$.

Thirdly, there was a positive and significant relationship between audit committee size and financial voluntary disclosure of listed manufacturing companies in Kenya (rho $=0.431$, p value $<0.05$ ). Further, there was a positive and significant relationship between gender diversity and financial voluntary disclosure of listed manufacturing 
companies in NSE (rho $=0.267$, $\mathrm{p}$ value $<0.05$ ). Finally, there was a positive and significant relationship between board ownership and financial voluntary disclosure of listed manufacturing companies in Kenya (rho $=0.515, \mathrm{p}$ value $<0.05)$.

Table 1 Correlation Analysis

\begin{tabular}{|c|c|c|c|c|c|c|c|c|c|c|c|}
\hline & $\mathbf{F}$ & $\mathbf{V}$ & D & Board size & \multicolumn{4}{|c|}{ Independent directors } & Audit committee Size & Gender diversity & Board ownership \\
\hline $\mathrm{D}$ & 1 & & & & & & & & & & \\
\hline $\mathrm{B}$ o a $\mathrm{d}$ size & 0 & 257 & $* *$ & 1 & & & & & & & \\
\hline Independent directors & 0 & 351 & $* *$ & 0.045 & 1 & & & & & & \\
\hline Audit committee Size & 0 & 431 & $* *$ & 0.032 & 0 & 5 & 3 & 2 & 1 & & \\
\hline Gender diversity & 0 & 267 & $* *$ & 0.215 & 0 & 3 & 1 & 5 & 0.208 & 1 & \\
\hline Board ownership & 0 & 515 & $* *$ & -0.212 & -0 & 4 & 6 & 1 & -0.133 & -0.302 & 1 \\
\hline
\end{tabular}

\section{Regression Analysis}

Multiple regression analysis was fitted to show the nature of the relationship between board size, independent directors, audit committee, gender diversity, board ownership and financial voluntary disclosure. These results were used to test the study hypothesis. Table 2 shows regression model summary which revealed that $45 \%$ of changes in financial voluntary disclosure can be jointly accounted for by board size, independent directors, audit committee, gender diversity and board ownership.

Table 2 Model Summary

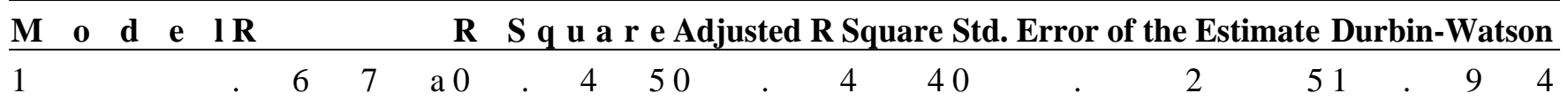

a. Predictors: (Constant), Board size, Independent directors, Audit committee, Gender diversity, Board ownership b. Dependent Variable: Financial Voluntary Disclosure

\section{Regression Coefficients}

Regression coefficients for the analysis are shown in Table 3 below

$Y_{i, t}=C+\beta_{1} X_{1 \mathrm{i}, \mathrm{t}}+\beta_{2} X_{2 \mathrm{i}, \mathrm{t}}+\beta_{3} \mathrm{X}_{3 \mathrm{i}, \mathrm{t}}+\beta_{4} \mathrm{X}_{4 \mathrm{i}, \mathrm{t}}+\beta_{5} \mathrm{X}_{5 \mathrm{i}, \mathrm{t}}+\dot{\varepsilon}_{\mathrm{i}, \mathrm{t}}$

$\mathrm{Y}=$ Voluntary Disclosure, $\mathrm{X} 1=$ Board Size, $\mathrm{X}_{2}=$ Independent Directors, $\mathrm{X}_{3}=$ Audit Committee, $\mathrm{X}_{4}=$ Gender diversity, $\mathrm{X}_{5}=$ Board ownership, $\dot{\boldsymbol{\varepsilon}}_{\mathrm{i}, \mathrm{t}}=$ error term, $\mathrm{i}=$ the specific firm, $\mathrm{t}=$ time in years

$\mathrm{Y}=0.45+0.25 \mathrm{X}_{1 \mathrm{i}, \mathrm{t}}+0.45 \mathrm{X}_{2 \mathrm{i}, \mathrm{t}}+0.38 \mathrm{X}_{3 \mathrm{i}, \mathrm{t}}+0.26 \mathrm{X}_{4 \mathrm{i}, \mathrm{t}}+0.56 \mathrm{X}_{5 \mathrm{i}, \mathrm{t}}+\dot{\varepsilon}_{\mathrm{i}, \mathrm{t}}$

The first hypothesis of the study stated that board size had no significant relationship with financial voluntary disclosure amongst manufacturing companies listed in NSE. Results of the study revealed positive and significant relationship between board size and financial voluntary disclosure of listed manufacturing companies in Kenya ( $\beta$ $=0.25$, p value $<0.05$ ). This implies that a unit change in board size increases financial voluntary disclosure by 0.25 units while holding independent directorship, audit committee size, gender diversity and board ownership constant.

The second hypothesis stated that independent directorship had no significant relationship with financial voluntary disclosure amongst manufacturing companies listed in NSE. Results of the study revealed positive and significant relationship between independent directorship and financial voluntary disclosure of listed manufacturing companies in NSE $(\beta=0.45, \mathrm{p}$ value $<0.05)$. This implies that an increase in independent directorship increases financial voluntary disclosure by 0.45 units while holding board size, audit committee size, gender diversity and board ownership constant.

The third hypothesis stated that audit committee size had no significant relationship on financial voluntary disclosure of listed manufacturing companies in NSE. Results of the study revealed positive and significant relationship between audit committee size and financial voluntary disclosure $(\beta=0.38, p$ value $<0.05)$. This implies that a unit change in audit committee size increased financial voluntary disclosure by 0.38 units while holding board size, independent directors, gender diversity and board ownership constant. 
The fourth objective of the study stated that gender diversity had no significant relationship with financial voluntary disclosure of listed manufacturing companies in NSE. Results of the study revealed positive and significant relationship between gender diversity and financial voluntary disclosure of listed manufacturing companies in NSE $(\beta=0.26, p$ value $<0.05)$. This implies that a unit increase in gender diversity increases financial voluntary disclosure by 0.26 units while holding board size, independent directorship, audit committee size and board ownership constant.

The fifth hypothesis stated that board ownership had no significant relationship with financial voluntary disclosure of listed manufacturing companies in NSE. Results of the study revealed positive and significant relationship between board ownership and financial voluntary disclosure of listed manufacturing companies listed in NSE $(\beta=0.56, p$ value $<0.05)$. This implies that a unit increase in board ownership increases financial voluntary disclosure by 0.56 units while holding constant board size, independent directorship, audit committee and gender diversity.

Table 3 Regression Analysis

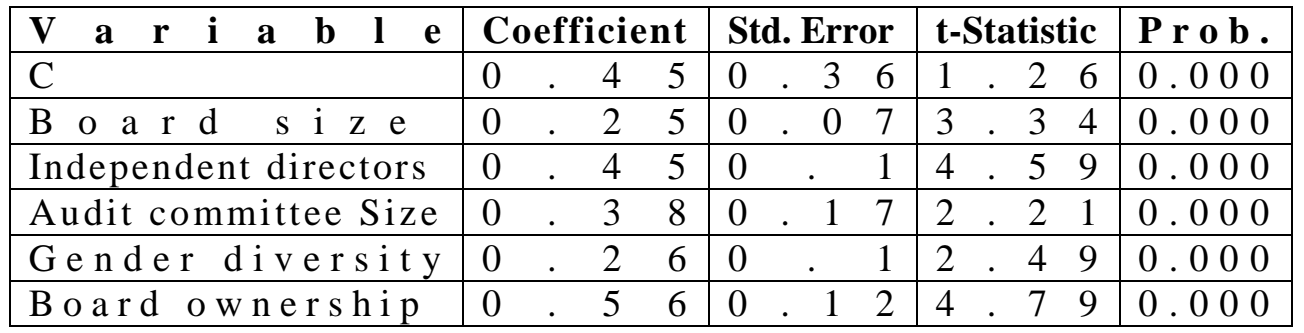

\subsubsection{ANOVA}

Analysis of Variance (ANOVA) consists of calculations that provide information about levels of variability within a regression model and form a basis for tests of significance. Analysis of variance was carried out and the results are shown in the Table 4. Results of the study revealed that board size, number of independent directors, size of audit committee, gender diversity and board ownership all had joint significant influence on voluntary disclosure among the listed manufacturing companies $(\mathrm{F}=101.5179, \mathrm{P}$ value $=0.00)$.

Table 4 ANOVA

\begin{tabular}{|c|c|c|c|c|c|c|c|c|}
\hline M o d e l & & Sum of Squares & D & $\mathbf{f}$ & Mean Square & $\mathbf{F}$ & $\begin{array}{lll}\mathbf{S} & \mathbf{i} & \mathbf{g} \\
\end{array}$ & 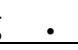 \\
\hline 1 & Regression & 127.405 & 5 & & 25.481 & 101.5179 & $\begin{array}{lll}0 & 0 & 0\end{array}$ & $0 \mathrm{a}$ \\
\hline & $\mathrm{R}$ e $\mathrm{s}$ i d u a 1 & 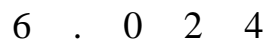 & 2 & 4 & $\begin{array}{lllll}0 & . & 2 & 5 & 1\end{array}$ & & & \\
\hline
\end{tabular}

a. Predictors: (Constant), Board size, Independent directors, Audit committee, Gender diversity, Board ownership b. Dependent Variable: Financial Voluntary Disclosure

\section{Conclusion and Recommendations}

Based on the study findings it can be concluded that corporate governance structure has significant contribution on financial voluntary disclosure. There is need for listed manufacturing companies to match their board size with their size. Secondly, manufacturing companies should embrace independent directorship this would aid in benefiting from heterogenous skills gathered. Thirdly, there is need to have fully functional audit committee, this would aid in minimizing agency and monitoring costs. Finally, there is need to ensure board membership complies with constitutional requirements so as to ensure full representation of different stakeholders.

\section{References}

Ayemere, I. L. \& Elijah, A., (2015). Audit Committee Attributes and Earnings Management: Evidence from Nigeria. International Journal of Business and Social Research, 5(4), 14-24.

Bansal, S., Lopez-Penez, M. V., \& Lazaro, R. A. (2018). Board Independence and Corporate Social Responsibility Disclosure: The Mediating Role of the Presence of Family Ownership. Journal of Administrative Science, 8(33),1-21.

Eng L. L. \& Mak Y. T. (2003). Corporate governance and voluntary disclosure. Journal of Accounting and Public Policy, 22(9),325-345. 
Fakhari, H., \& Pitenoei, Y. R. (2017). The Impact of Audit Committee and Its Characteristics on the Firms' Information Environment. Iranian Journal of Management Studies, 10(3), 577-608.

Gul F. A. \& Leung S. (2004). Board leadership, outside directors' expertise and voluntary corporate disclosures. Journal of Accounting and Public Policy, 23 (5), 351-379.

Gul, F., Srinidhi, B., \& Ng, A.C. (2011). Does board gender diversity improve the informativeness of stock prices? Journal of Accounting and Economics, 5(1), 314-338.

Jensen, M. C., \& Meckling, W. H. (1976). Theory of the firm: managerial behavior, agency costs and ownership structure. Journal of Financial Economics, 3(4), 305-360.

Latif, B., Shahid, M. N., Haq, M. Z., Waqas, H. M., \& Arshad, A., (2018). Impact of Corporate governance on Firm Performance: Evidence from Sugar Mills of Pakistan. European Journal of Business Management, 5(1), 51-59.

Lim, S., Matolcsy, Z., \& Chow, D. (2007). The Association between board composition and different types of voluntary disclosure. European Accounting Review, 16(3), 555-583.

Liu, G. and Sun, J. (2010). Director tenure and independent audit committee effectiveness. International research journal of finance and economics,51, 176- 189.

Okoth, B., \& Coskun, M., (2016). Evaluating the Impact of Corporate Governance on Firm Performance Using Board Index. Journal of Finance and Accounting, 4(4), 23-34.

Ramadhan, S. (2014). Board Composition, Audit Committees, Ownership Structure and Voluntary Disclosure: Evidence from Bahrain. Research Journal of Finance and Accounting, 5(2),124-138.

Setiany, E., Hartoko, S., Suhardjanto, D., \& Honggowati, S., (2015). Audit Committee Characteristics and Voluntary Financial Disclosure. Review of Integrative Business and Economic Research, 5(6), 25-38.

Shehata, N. F. (2013). How could board diversity influence corporate disclosure? Corporate Board: Role, Duties \& Composition. Journal of Accounting and Finance, 9(3), 42-50.

Shehata, N. F., (2014). Theories and Determinants of Voluntary Disclosure. Accounting and Finance Research, $3(1), 18-26$.

Sweiti, I. M., \& Attayah, O. F., (2016). Critical Factors Influencing Voluntary Disclosure: The Palestine Exchange "PEX". Global Journal of Management and Business Research Finance, 13(6), 8-16.

Tian, Y., \& Chen, J. (2009). Concept of Voluntary Information Disclosure and A Review of Relevant Studies. International Journal of Economics and Finance, 1(2), 55-59.

Wang, K., Sewon, O. M. \& Claiborne, C., (2008). Determinants and consequences of voluntary disclosure in an emerging market. Evidence from China. Journal of International Accounting Auditing and Taxation, 17(1), 14-30.

Yanesari, A. M., Gerayli, M. S., Ma'atoofi, A. R., \& Abadi, A. Z. (2012). Board Characteristics and Corporate Voluntary Disclosure: An Iranian Perspective. Archives Des Sciences. Iranian Journal of management Science, 65(5), 478-484.

Zhou, J. \& Chen, K. Y. (2004). Audit committee, board characteristics and earnings management by commercial banks. Journal of Accounting and Finance, 4(5), 1-34.

Zhou, M. M., \& Panbunyuen, P. (2008). The association between board composition and different types of voluntary disclosure. A quantitative study of Chinese and Swedish listed companies. Unpublished Master's thesis. 